\title{
Foreign acquisitions and firm performance: The moderating role of prior foreign experience
}

\author{
Henry Agyei-Boapeah \\ The York Management School, University of York, Freboys Lane, York, YO10 5GD, UK. \\ E-mail: henry.agyei-boapeah@york.ac.uk or boapeah@yahoo.com
}

\begin{abstract}
This paper relies on a sample of 9,419 acquisitions by 1,443 UK firms during 1988 to 2014 to investigate the impact of foreign acquisitions on corporate performance. Moreover, the moderating role of firms' prior exposure to foreign markets on the foreign acquisition-performance link is explored. The paper finds that, on average, foreign acquisitions have a negative impact on corporate performance. However, the negative impact of foreign acquisitions disappears under two circumstances: (1) when domestic firms undertake foreign acquisitions; and (2) when highly experienced multinationals undertake foreign acquisitions. Collectively, the findings imply that the benefits (costs) associated with foreign acquisitions are greater (lower) for new entrants into foreign markets and for highly experienced multinationals.
\end{abstract}

Key words: Internationalization; foreign acquisition; prior foreign experience; financial performance; $M \& A$

JEL classification: G32; G34 


\section{Introduction}

Recent figures suggest that growth by international diversification continues to be an important strategic tool for firms. Global foreign direct investments rose by $9 \%$ to $\$ 1.45$ trillion in 2013 and this surge in foreign direct investment was expected to continue to about $\$ 1.8$ trillion in 2016 . Furthermore, the United Nations Conference on Trade and Development (UNCTD) reports that the 100 largest corporations worldwide in 2013 had 59\% of their assets and 65\% of their sales in foreign markets. Importantly, the report reveals that a greater proportion of these foreign direct investments tend to be by means of mergers and acquisitions. These developments, perhaps, underscore the continuing relevance of posing the following questions: (1) What is the net impact of increasing levels of foreign acquisitions on key corporate performance measures that are of interest to managers? and (2) Is the net impact of foreign acquisitions on corporate performance higher or lower for firms with little or no experience in foreign markets? This paper attempts to find answers to these two related questions.

Since foreign acquisitions represent an important vehicle for accessing foreign markets, they are likely to be associated with most of the benefits and costs of engaging in international business. While the value impact of engaging in international business has received some attention in the international business and management literature, not much attention has been paid to how the various modes of entering into foreign markets may influence the benefits/costs of international business activities, leading to mixed conclusions in the literature. ${ }^{1}$ Put differently, a bulk of these studies has implicitly assumed that the benefits and costs as well as the risks associated with international business activities are symmetric across the various modes of entry into foreign markets including exporting, joint venture, mergers and acquisitions, and greenfield investments (see e.g. Pangarkar, 2008; Lu \& Beamish, 2001; Lu \& Beamish, 2004). There has, therefore, been very little attempt by researchers to control for the mode of entry into foreign markets when investigating the internationalizationperformance link. Making a distinction between the value impact of the various modes of foreign market entry is important because Shimizu et al. (2004) and Agyei-Boapeah (2015) argue that while

${ }^{1}$ For instance, Sullivan's (1994) literature review included about 24 studies on this topic with the earliest study published in 1971. 
internationalization can be achieved in a variety of ways (e.g. greenfield investments, foreign acquisitions, exports, formation of alliances and joint ventures), the risks/costs associated with the equity entry modes (e.g. foreign acquisitions and greenfield investments) far outweigh those of the non-equity entry modes (e.g. exports, formation of alliances, etc.). Thus, it is possible for some entry modes with lower costs/risks (e.g. exports) to lead to positive internationalization-performance link while others with greater costs/risks (e.g. foreign acquisitions) result in negative relationships. For instance, it is likely that political risks, coordination costs, as well as integration costs will be greater for firms that become international through the purchase of existing assets/firms in other countries, compared to those international firms that merely export to foreign countries. This is because while exporting firms may have little or no foreign assets in host countries, acquiring firms do establish a physical presence in host countries which imposes additional costs/risks/complexities such as increased risk of foreign asset expropriation (Agyei-Boapeah, 2015). Therefore, it is plausible for the relationship between internationalisation and performance to vary for the various modes of entering foreign markets. As a first step towards recognising the potential role of the mode of entry into foreign markets, this paper focuses on how a specific mode of entry into foreign markets (i.e. foreign acquisitions) may impact firms' performance.

In the interest of robustness and to focus on operational variables that are of much relevance to corporate managers, this article considers the impact of foreign acquisitions on four key performance measures: (1) the accounting-based return on assets (ROA); (2) the market-based Tobin's Q (Q); (3) operating cash-flow (OCF); and (4) operating cost. A key problem with the use of one or two performance measures is that the chosen measure may fail to be representative of firm performance at a point in time, especially if the objective function of majority of the sample firms is different from the chosen performance measure. As noted by Pangarkar (2008), most small- and medium-enterprises in their early stages of operations do place a strong emphasis on sales growth, but not necessarily on profitability. Similarly, firms may sometimes strategically choose to emphasize cost savings/efficiencies or cash-flow improvements ahead of profitability. In such circumstances, an analytical focus on corporate profitability (e.g. return on assets) alone may understate the true performance achieved by these firms as well as distort the relationship between internationalization 
and performance. The use of a range of performance measures in the current article should help increase the likelihood of capturing the value impact of foreign acquisitions for firms that may have a broad objective function.

Another important contribution of this paper is to test whether an acquiring firm's prior exposure to foreign markets (or its stage of internationalization) enhances or impedes the benefits it reaps from increasing levels of internationalization. In this regard, the paper first distinguishes between the crossborder effect for domestic corporations (i.e. firms with no prior exposure to foreign markets and may thus be entering foreign markets for the first time) on the one hand and multinational corporations (i.e. firms with prior exposure to foreign markets and perhaps want to increase their foreign presence) on the other hand. Further analysis then focuses on existing multinationals and considers how the foreign acquisition effect may vary for: (1) multinationals with little exposure to foreign markets; (2) multinationals with moderate exposure to foreign markets; and (3) multinationals with significant exposure to foreign markets. These analyses on prior exposure to foreign markets are motivated by the literature on foreign market experience (e.g. Very \& Schweiger, 2001; Davidson, 1980; Johanson \& Vahlne, 1977).

The issues explored in this article are based on a sample of 9,419 acquisitions by British firms during 1988-2014. The next section relies on the extant literature to establish the potential link between foreign acquisitions and corporate performance, as well as the moderating role of firms' prior exposure to foreign markets on the foreign acquisition-performance nexus. Section 3 describes the data and methods employed for the study's empirical analysis. Sections 4 and 5 present and discuss the results, and test the robustness of the results to alternative specifications. Finally, Section 6 concludes the paper.

\section{Related literature}

\subsection{Why should foreign acquisitions impact corporate performance?}

Mergers and acquisitions of target companies in foreign countries is a frequently used corporate strategy to obtain and/or increase a firm's levels of international business activity (Shimizu et al., 2004). Its popularity as a mode of engaging in international business over other modes such as 
greenfield investments stems from the speed with which the acquiring firm can establish a presence in a foreign market. As soon as a target firm is identified in the preferred foreign location and the agreed price paid, the acquiring firm obtains full control of the existing resources and capabilities of the target firm including its local knowledge and business experience. While other foreign market entry modes such as joint venture or cooperation may also enjoy the speed advantage, they often don't give the firm full control over existing resources in the foreign market. Moreover, the sharing of proprietary business information among partners may sometimes be deemed dangerous which may reduce the potential benefits to be reaped from the operations. These reasons, among others, make foreign acquisitions an advantageous means of entering new markets especially for firms with little or no experience of the new foreign market as long as the right target firm is identified.

Since making foreign acquisitions often result in an increase in the firm's levels of international business or diversification, the current article draws from the international business and diversification literature to establish a link between making foreign acquisitions and firm performance. There is broad agreement in the literature on the existence of some benefits of international diversification which can be harnessed to improve corporate financial performance. Relative to purely domestic firms, international firms may enjoy greater cost efficiencies primarily due to greater volume of business and the ability to exploit economies of scale (Pangarkar, 2008; Hout, Porter, \& Rudden, 1982). For instance, the wider market and greater volume of business of an international firm may justify its investments in a state-of-the-art manufacturing plant whereas a purely domestic rival may not be able to justify such an investment. In addition, international firms could augment their competitiveness in both home and host markets by exploiting the unique resource endowment and location-specific advantages that exist in each of their host countries (Kogut \& Chang, 1991). International firms, for example, could create competitive advantages by siting specific activities in particular locations (e.g. labour-intensive activities in low-wage countries) in order to minimize their costs.

Another important benefit enjoyed by international firms is flexibility due to the possibility of arbitrage. Differences across countries can be exploited by shifting production volumes/locations in response to wage and tax rates. It is also possible for international firms to reduce their taxes by 
charging appropriate transfer prices to sister entities. For example, the $\$ 160$ billion merger and acquisition deal announced in 2015 between the US pharmaceutical company, Pfizer, and the Irish drug company, Allergan, was structured in a way that makes the new company's profit to be subject to Ireland's corporation tax rate of $12.5 \%$, which is much lower than the $35 \%$ Pfizer pays in the US. This is expected to contribute to the deal's savings which was estimated to be around $\$ 2$ billion in the first three years. ${ }^{2}$ Furthermore, international firms can benefit from the diversity of environments in which they operate by enjoying tremendous learning opportunities when conducting business in international markets (Kostova \& Roth, 2002). Such business knowledge could generate competitive advantage for international firms and lead to superior performance. Finally, international firms may enjoy lower earnings volatility as they are able to receive cash flows from imperfectly correlated foreign markets (Reeb, Mansi, \& Allee, 2001). This leads to reduced risks/borrowing costs and financing advantages (Agyei-Boapeah, 2017). Overall, these arguments suggest that engaging in international business or diversifying internationally should result in better corporate performance.

However, corporate international diversification is not a guaranteed route to success due to the increased cost/risks associated with it, which (in turn) could result in net declines in corporate financial performance. Burgman (1996) argues that international firms may face foreign exchange risks which impose additional costs and complexities in their operations. Also, the transaction costs theory (see Pangarkar, 2008; Hitt et al., 1997; Jones \& Hill, 1988) suggests that international diversification poses difficult challenges to the management of multinational corporations. For example, the management of multinationals will have to deal with the loss or distortion of information as it passes through several layers of hierarchy. More so, since each host country has a unique business environment, management will have to deal with possible diseconomies that could arise from the coordination of operations across disparate host countries. It is also possible for international firms to have duplication of operations at each new country, and all these challenges/complexities can result in increased coordination, communication, and governance costs for international firms. Finally, international diversification (especially when it involves the establishment of a physical presence in a

${ }^{2}$ http://www.bbc.co.uk/news/business-34900344 
new and unknown foreign country) is associated with a liability of foreignness (Hymer, 1976) because the international firm (particularly new ones) cannot conduct business as effectively as a local firm. Being foreign implies that mistakes in various business decisions are more likely. Such mistakes and their corrections could again lead international firms to have higher costs and worse performance.

Collectively, it is theoretically possible for increased levels of international business activity to be either positively or negatively related to performance depending on the net effect of the benefits and costs of internationalization in a particular sample. Thus, to the extent that foreign acquisitions lead to higher levels of international business activity, undertaking foreign acquisitions should impact on the firm's performance positively or negatively.

\subsection{Why should the acquiring firm's prior foreign market experience matter?}

Since the impact of foreign acquisitions on firm performance is primarily due to the presence of competitive advantages and/or disadvantages in foreign business, the current paper argues that there should be systematic cross-sectional variations in the performance impact of foreign acquisitions among firms at the early stages of internationalization and their counterparts at a more advanced stage. This is because the two groups of firms may have different levels of foreign market experience and knowledge, and hence, have different abilities in realizing the gains associated with international operations as well as dealing with the difficulties/challenges associated with international business activities.

It is widely acknowledged that the benefits of internationalization may not be realized when postimplementation processes (e.g. acculturation and integration) are not effectively managed (Very \& Schweiger, 2001). Thus, the ability of firms to manage the post-implementation processes may determine whether or not they achieve any competitive advantages associated with undertaking foreign acquisitions. Since a firm's level of experience in foreign market operations may be related to its ability to manage subsequent international business activities, it is likely that firms at a more advanced stages of internationalization (i.e. those with more experience in foreign markets) will enjoy superior performance relative to those at the early stages (i.e. firms with little or no experience in foreign markets). This is because with increasing foreign market experience, firms acquire a general 
knowledge of doing business in foreign markets which helps them to reduce mistakes as well as make more competent decisions in relation to future foreign business expansions (e.g. Davidson, 1980; Johanson \& Valne, 1977). Specifically, it is possible that experienced firms will use their extensive foreign market knowledge acquired over a number of years in a learning-by doing process to develop and implement effective mechanisms to mitigate the increased costs associated with internationalization (Haleblain \& Finkelstein, 1999; Barkema \& Vermeulen, 1998).

A practical case in point is the rapid global expansion by the British retail multinational - Marks \& Spencer $(M \& S)$ - in 2007, after learning valuable lessons from its previous unsuccessful overseas adventure in the 1980s and 1990s. In announcing his plans to enter the Chinese market in 2008, Marks \& Spencer's chief executive stated emphatically that “...we made some mistakes before [in our global expansions] but you wouldn't be a successful business if you didn't...". With an already significant overseas presence (257 stores in 36 countries), Mark \& Spencer could draw on its wealth of knowledge and experience in overseas operations to give its plan of expanding into China a greater likelihood of success. ${ }^{3}$ In sum, relative to other firms, the experiential knowledge of firms at advanced stages of internationalization is likely to lead to higher (lower) benefits (costs) for them when they make foreign acquisitions.

It is also conceivable that firms at the early stages of internationalization (especially new foreign market entrants) may rather enjoy higher advantages over those at the advanced stages. This is because, besides the liability of foreignness, most of the major costs associated with international business activity (e.g. communication costs, governance costs, and coordination costs) are likely to be exacerbated at higher levels of international activity (Lu \& Beamish, 2004; Jones \& Hill, 1988). For instance, firms at the advanced stages of the internationalization process tend to have more extensive networks of foreign subsidiaries in more and more countries, which, in turn, escalate their governance and coordination costs, and ultimately lead to lower performance. Moreover, some scholars argue that firms first expand to countries that are relatively close (in psychic distance) to the home country before later moving into more distant and risky countries (e.g. Krapl, 2015; Johanson \& Vahlne,

\footnotetext{
${ }^{3}$ The Independent newspaper on $7^{\text {th }}$ November 2007. See $\underline{\text { http://www.independent.co.uk/news/business/analysis-and- }}$ features/british-retailers-going-global-744882.html
} 
2009). The implication is that the international activities of early-stage firms (particularly new entrants) are likely to be less risky, less complicated, and less costly, whereas those of advanced staged firms are likely to be more risky and costly. In fact, there is empirical evidence to show that the risk-increasing effect of international diversification is stronger for firms that are in more advanced stages of the internationalisation process (see Krapl, 2015). Thus, it is plausible for there to be worse performance for advanced-stage firms relative to early-stage firms in the internationalization process.

Collectively, the moderating role of a firm's stage of internationalization on the performance impact of foreign acquisitions is an empirical matter to be resolved by empirical research. Hence, this paper relies on a large sample of foreign acquisitions made by domestic and multinational British firms to empirically test this matter.

\section{Methodology}

\subsection{Estimation method}

The primary objective of this paper is to examine whether a firm's decision to increase its level of international diversification (i.e. via foreign acquisitions) in year $t$ has a significant impact on its financial performance in year $t+1 .{ }^{4}$ To empirically undertake this analysis, one must determine whether the observed post-acquisition performances for foreign acquirers are significantly higher or lower than what they would have been if these firms had not engaged in foreign acquisitions to increase their levels of international diversification. However, the latter outcome is unobservable. A possible analysis would be to compare the performances of foreign acquirers with those of nonacquiring firms. The problem with this form of analysis is that firms select themselves into the different groups (acquirers vs. non-acquirers) based on characteristics that might also influence the observed outcome. Within the context of this paper, it may be the case that firms with better performance are more likely to engage in acquisitions. Thus, results based on a comparison between acquirers and non-acquirers are likely to suffer from selection bias.

\footnotetext{
${ }^{4}$ When the performance window is extended to cover years $t+2$ and $t+3$, the study's key findings largely remain qualitatively unchanged. However, these approaches reduce our sample substantially.
} 
In order to minimize this potential selection bias, the current article follows recent studies such as Agyei-Boapeah (2015) and Bertrand \& Capron (2015) to select a control sample of acquirers rather than non-acquirers. Since the primary focus is to investigate the impact of increasing internationalisation (via foreign acquisitions) on the performance of foreign acquirers, domestic acquirers are relied upon to serve as a control group. Specifically, the sample of firms that engaged in domestic acquisitions during the sample period (1988-2014) served as the control sample for the firms that engaged in foreign acquisitions (i.e. the main sample). It is important to note that since the empirical (multivariate) model utilised in the current paper directly controls for firm size and industry, the control firms are not matched by size and/or industry. ${ }^{5}$

The goal for using domestic acquirers as a control group is to construct a control group of firms that are also active in the market for corporate control, except that their acquisition activities did not result in increases in their levels of international diversification. Since firm's foreign operations may increase when they undertake foreign acquisitions but are likely to remain unchanged in domestic acquisitions, ${ }^{6}$ the post-acquisition performance of domestic acquirers could provide a reasonable proxy for the expected post-acquisition performance of foreign acquirers had their acquisition decisions not increased their foreign operations. Therefore, the results on the foreign acquisition effect on firm performance could be interpreted in relations to firms' actions (acquisitions) which did not increase their foreign operations. ${ }^{7}$

The sample of foreign acquirers and the control sample of domestic acquirers are then used to implement the difference-in-differences (DID) estimator in a multivariate regression framework. This approach basically compares the difference in the performance of foreign acquirers with that of

\footnotetext{
${ }^{5}$ The size and industry differences between the main sample (cross-border acquirers) and the control sample (domestic acquirers) and their effect on the performance of the firms can be dealt with by either: (a) constructing a size-and-industrymatched control sample; or (b) directly controlling for firms size and industry in a multivariate framework. The present paper chose the latter approach because it has two main advantages: (1) it helps to directly observe/quantify the size and industry effect on firm performance; and (2) it increases the explanatory power of the regression model.

${ }^{6}$ In untabulated results, this paper finds that firms' levels of international diversification (as measured by their foreign assets ratio) significantly increase by about 6 percentage points following cross-border acquisitions. However, there is no statistically significant change in the levels of international diversification when firms undertake domestic acquisitions.

${ }^{7}$ Where a firm undertakes both foreign and domestic acquisitions in the sample period, that firm appears twice - once in the treatment (foreign M\&A) sample and also in the control (domestic M\&A) sample. In robustness testing, such firms making both domestic and foreign acquisitions in the sample period are dropped and the analysis re-done, but the results and main conclusions do not change qualitatively. Again, the results are robust to the inclusion of transaction value to control for the differences in the size of foreign and domestic acquisitions. These results are untabulated for the sake of brevity, but are available upon request.
} 
domestic acquirers while controlling for the other determinants of firms' performance (e.g. firm size, financial leverage, etc.). Specifically, the DID estimation model below, Eq. (1), is the baseline model used for the empirical analyses. The parameters of the model are estimated using the random-effects generalised least squares (GLS) panel estimation procedure.

$$
\text { Performance }_{i t}=\beta_{1}+\beta_{2} F A_{i}+\beta_{3} \text { Post }_{t}+\beta_{4}(F A * P o s t)_{i t}+\beta_{5} X_{i t}+\varepsilon_{i t}
$$

In Eq. (1) above, $\beta_{1}$ is the intercept, $F A$ is the foreign acquisition dummy which is equal to one if the observed firm is a foreign acquirer, and zero for the control group of firms (domestic acquirers). The $F A$ dummy $\left(\beta_{2}\right)$ is expected to capture the general differences in firms' performance which emanate from the inherent differences between foreign acquirers and the control firms. It may be the case that there is a systematic difference in the performances of firms that undertake foreign acquisitions and the control group of firms. Thus, $\beta_{2}$ should capture the impact of such differences in the two sample groups on performance.

Post, in Eq. (1) above, is the post-acquisition dummy which is equal to one (zero) if the observation is for the year $t+1$ (year $t-1$ ). This variable (and its parameter estimate, $\beta_{3}$ ) should capture the general changes in corporate performance over the pre-and post-acquisition periods (i.e. from $t-1$ to $t+1)$. The inclusion of this variable reflects the fact that firms' performance may change for most firms (whether or not they engaged in foreign acquisitions) during some periods due to general economic conditions (e.g. low interest rates, economic growth, etc.). Indeed, acquisitions may be more likely in periods of credit availability and high stock market performance which make it easier for firms to obtain funding for their investments. So, it is possible for firms, in general, to experience changes in their profitability during periods of high acquisition activity. Therefore, the inclusion of $\beta_{3}$ in Eq. (1) helps to control for the macro-economic conditions (e.g. booming stock markets) that could induce changes in corporate performance over the pre- and post-acquisition periods (i.e. $t-1$ and $t+1)$.

The main parameter of interest for the current article is $\beta_{4}$ (i.e. the coefficient for the interaction dummy between FA and Post) since it represents the average foreign acquisition impact on firms' 
financial performance. It $\left(\beta_{4}\right)$ shows the change in corporate performance which is solely due to the completion of a foreign acquisition. It is, therefore, hoped that $\beta_{4}$ reflects the impact on a firm's performance following a corporate activity which increases its levels of international diversification. Consequently, a negative (positive) and significant coefficient estimate of $\beta_{4}$ would be consistent with the view that increasing levels of international diversification (via foreign acquisitions) is associated with reduced (improved) acquirers' performance.

It must be noted that in testing the foreign acquisition effect for domestic and multinational firms, Eq. (1) is slightly modified by interacting $\beta_{4}$ with dummies for the different types of acquirers that are of interest to this study (e.g. first time entrants into foreign markets, and acquirers with prior exposure to foreign markets). Therefore, the empirical analyses contained in this paper are conducted using several related models. The first model is the baseline model in Eq. (1) above, while the remaining models are variants of the baseline regression model.

\subsection{Measures of the dependent (performance) variable}

Grant et al. (1988) note that findings about the relationship between diversity and performance appear to be susceptible to choice of performance measures. Aware of this critique, this paper deploys a broad range of performance measures in an attempt to increase the likelihood of representing the complex set of goals that firms may have at different points in time (e.g. improve profitability or cash flow, cut cost, etc.). Specifically, this article utilises four different but related measures of financial performance (return on asset, Tobin's Q, operating cash flow, and operating cost) to assess the firm's performance impact of increasing levels of internationalization. Whether or not these four measures are correct proxies of firm performance is a subject of continuing debate in the literature. Each performance measure has its own strengths and limitations.

The first performance measure is the return on asset (ROA). As an accounting-based measure of performance, the return on asset is criticised for conveying little information about the firm's economic rate of return and for being subject to management discretion and manipulation. Nonetheless, ROA remains a popular performance measure in the literature as well as a useful 
measure of performance for corporate managers since it serves as the basis for major corporate decisions such as executive compensation and undertaking new investment projects. Following the extant literature, the current paper measures ROA as the ratio of net income (i.e. pre-tax profit minus corporate tax) to the book value of total assets.

Another popular measure of firm performance is the Tobin's Q which is generally defined as the ratio of the market value of the firm to the replacement cost of its assets. As a market-based measure, it is often seen by researchers as providing more relevant (economic) performance information to investors. Critiques argue that Tobin's Q is a better proxy for a firm's growth opportunity than its performance. Other market-based measures, such as abnormal stock return, have been suggested in the literature. However, abnormal stock return, as a proxy for firm performance, is most appropriate for all-equity firms. Moreover, there are econometric challenges and debates over the estimation of the market model used in abnormal stock return research. As in Agyei-Boapeah et al. (2018), this paper defines Tobin's Q as total assets minus book equity plus market equity divided by total assets.

The third performance measure utilised in this study is the operating cash flow (OCF) which is an important source of information for creditors. The operating cash flow measure is similar to the ROA. However, to the extent that corporate managers use their discretion and superior information to opportunistically manipulate accounting profit, ROA could become a less reliable measure of firm performance and cash flow measures could thus become more preferable. The operating cash flow measure of performance is not without criticism. Over finite internals, reporting realized cash flows is not necessarily informative because realized cash flows have timing and matching problems that cause them to be a "noisy" performance measure. The operating cash flow measure is defined in this paper as the sum of earnings before interest and tax, depreciation and amortisation expenses, and research and development $(\mathrm{R} \& \mathrm{D})$ expenses divided by total assets.

The final performance measure is the operating cost (OC) measure. This is not very common in the empirical literature, perhaps, because other performance measures (e.g. ROA) are functions of the operating cost performance measure. However, its inclusion in this study as a performance measure is motivated by the emphasis on costs in internationalization theory. As noted earlier in Section 2, the impact of foreign acquisition on firm performance is mostly through its effect (increase or decrease) 
on the cost structure of the firm. Thus, the operating cost variable helps to directly observe the foreign acquisition impact on the firm's operating cost. To the best of my knowledge, this is the first study to directly consider this issue. Operating cost is defined as gross profit minus operating profit divided by total assets.

\subsection{The control variables}

In order to reduce the residual variance of Eq. (1) and its related models, a vector of control variables $(X)$ is included in all the regression models used for the analyses. The choice of these variables was guided by intuition and the literature on firm performance and internationalization (e.g. Mehran, 1995; Lu \& Beamish, 2001; Lu \& Beamish, 2004; Pangarkar, 2008). First, the number of years for which a firm has been listed on Datastream is included to proxy for the firm's age and to control for the general business experience of the firm since older firms may be more experienced, and hence, have superior performance. It is also plausible for older firms to have inferior performance since their products are likely to be at the declining stage of the product life cycle. Second, sales per employee is included to control for the employee productive capacity of the firm since firms with higher employee productivity are likely to perform better.

Third, the effect of firm size is controlled for using the natural log of sales as a proxy. Larger firms can enjoy more scale economies as well as have greater resource pool (Agyei-Boapeah et al., 2018), which could result in better performance. Fourth, the ratio of total debt to total assets is included to control for financial leverage since the use of debt by firms is associated with both advantages (e.g. tax savings) and disadvantages (e.g. cost of financial distress) which ultimately affect firm performance. Fifth, asset tangibility is included to control for the real capital intensity of the firm since real assets largely represent the physical productive capacity of a firm. This is measured as the ratio of net property, plant, and equipment scaled by total assets. Sixth, the firm's technological capabilities is controlled for by including the ratio of research and development (R\&D) expenses to total assets. Seventh, since a number of firms had missing R\&D values, a dummy variable is also included to control for such firms. 
Eighth, a dummy for multi-product segment firm is included to control for product diversification. Product diversified firms may enjoy better performance because they face lower cash flow volatility (Agyei-Boapeah, 2017). However, they can also suffer inferior performance if they face higher agency costs. Ninth, the effect of monetary influences is controlled for by including the US dollarsterling exchange rate. The dollar is used because it is frequently used as a reference point for exchange rates. Apart from controlling for the monetary influences of international business on firm profitability, the US dollar-sterling exchange rate also controls for general macroeconomic conditions prevailing across the sample period. ${ }^{8}$ In addition, industry dummies are included to control for industry fixed effects. Finally, the regression model contains an error term, $\varepsilon_{i t}$.

\subsection{Data and descriptive statistics}

In terms of the data for the analysis, all completed acquisitions (including foreign and domestic deals) from 1985-2015 by non-financial publicly listed UK acquiring firms were collected. ${ }^{9}$ The data on the dates of acquisition and the target nations are obtained from Thomson One Banker's Merger and Acquisitions database. It was decided to only keep deals for which the acquirer is not a governmental agency or a healthcare organisation since such organisations are generally not profitoriented. Moreover, the relevant annual accounting data ${ }^{10}$ for acquiring firms had to be available in Datastream for two years (the years immediately before and after the focal acquisition). Applying these criteria resulted in a sample to 9,419 deals made by 1,443 UK firms during 1988-2014. The final dataset utilised in the empirical analyses is obtained by constructing a 2-period panel dataset for the 9,419 acquiring firms. For each acquiring firm in year $t, 2$-years of observations are required in order to undertake the empirical analyses (i.e. $t-1$ and $t+1$ ). Thus, observing these 9,419 acquiring firms over a 2-year period produces observation units of 18,838 firm-years (i.e. 9,419 firms x 2 years $=$ 18,838) which are used in the empirical analyses.

\footnotetext{
${ }^{8}$ In untabulated results, the US dollar-sterling exchange rate variable is dropped and the effect of macroeconomic influences is captured by the inclusion of year dummies for each year in the sample period (1988-2014, except 1988 which was used as a reference year). The results based on this specification are qualitatively similar to our reported results.

${ }^{9}$ Consistent with the tradition in corporate finance research, financial firms (e.g. banks, insurance companies, etc.) are excluded from the study because they have special asset compositions and are also subject to stricter government regulations which make them different from other firms.

${ }^{10}$ That is, the data to calculate firm performance and the control variables (e.g. firm size, ROA, Tobin's Q, etc.) used in the regression model should be available.
} 
Table 1 presents the breakdown of acquisitions by year, type, (foreign vs. domestic M\&A), and the prior foreign exposure of the acquirer (multinational vs. domestic firm). A foreign acquisition is defined to include deals in which the target country is different from the UK. Out of the 9,419 deals, 3,729 (40\%) are foreign and 5,690 (60\%) are domestic. However, during the latter years (i.e. 20012014), the gap between the number of foreign and domestic deals has narrowed $(2,089$ vs. 2,634$)$ which reflects the rising trend in foreign acquisitions over recent years. This rising trend in foreign acquisitions is also revealed by changes in the proportion of cross-border acquisitions to total acquisitions over the years (see Table 1).

\section{[INSERT TABLE 1]}

When the deals are differentiated by the type of acquirer, $61 \%$ and $39 \%$ of the deals are made by multinationals and domestic firms, respectively. It is interesting to note that during the latter years (i.e. 2001-2014), whilst the proportion of domestic firms shrunk, that of multinationals surged (33\% vs. $67 \%$ ), suggesting that more and more businesses are becoming international in recent years. Firms are classified as multinationals (i.e. those firms with prior exposure to foreign markets) if they have reported non-UK assets or sales on Datastream, and as domestic firms (i.e. firms without prior foreign market exposure) if they have no foreign assets or sales. In terms of the time period, over $93 \%$ of the deals were completed between 1991 and 2014, implying that the results are more likely to reflect recent deals.

\section{[INSERT TABLE 2]}

Table 2 reports the descriptive statistics and correlation matrix for the study's variables. The statistics are based on data observations from the pre-acquisition years. According to the data, the average sample (acquiring) firm is profitable; with a return on asset of 4\%, a Tobin's Q of 1.96, and an operating cash flow ratio of $12 \%$ of assets. These statistics are in line with studies that find acquiring firms to be generally profitable, and seem to confirm some practitioners' view that growth by mergers and acquisitions are a natural progression following remarking performance by firms (e.g. Berkovitch and Narayanan, 1993; Hodgkinson and Partington, 2008; Agyei-Boapeah, 2017). Thus, the acquiring firms in our sample may well represent well-performing firms whose managers may be very confident in their abilities. 
Table 2 also shows a strong positive correlation between the key performance variables (i.e. return on assets, Tobin's Q, and operating cash flow ratio). The correlation between return on assets (ROA) and operating cash flow ratio (the accounting-based performance measures) is as high as 0.91 , whilst the correlation between the accounting-based performance measures and the market-based performance measure (Tobin's Q) is around 0.51 . These correlation statistics are significant at $1 \%$ level and the high correlation between the accounting-based and market-based performance measures is consistent with the literature (Mehran, 1995). Finally, the descriptive statistics suggest that the correlation between the key performance measures and the control variables are largely consistent with expectations. For example, the return on assets and the operating cash flow ratio (and sometimes the Tobin's Q) are positively correlated with firm age, firm size, capital intensity, and R\&D expenditure; but negatively correlated with financial leverage. Again, these relationships are in line with the extant literature (see e.g. Lu \& Beamish, 2004).

\section{Results and discussions}

\subsection{The foreign acquisition effect on financial performance}

Table 3 presents the multivariate regression results. The reported results are based on 12 different models. The dependent variable for Models 1, 5, and 9 is return on asset (ROA), and the dependent variable for Models 2, 6, and 10 is Tobin's Q. Operating cash flow ratio (OCF) is the dependent variable for Models 3, 7, and 11, and operating cost ratio (OC) is the dependent variable for Models 4, 8 , and 12 .

Models 1-4 present results for the test of foreign acquisition effect on performance. The results across the four performance measures indicate that foreign acquisitions, on average, result in significant declines in the acquirers' performance. Specifically, the completion of a foreign acquisition by a firm is associated with reductions of about $0.7 \%$ in ROA and operating cash flow, a $5.6 \%$ dip in its Tobin's Q, and a 1\% rise in operating cost. All these performance changes are statistically significant at conventional levels. Thus, the evidence seems to favour the view that the costs of internationalization are generally greater than the benefits for most firms at least in the shortterm (Lu \& Beamish, 2004; Burgman, 1996). Since mergers and acquisitions are generally long-term 
projects, in untabulated results, the tests are repeated for performance measures covering the three years post-acquisition, and the results remain qualitatively similar. Mindful of the challenge of inferring merger-related performance changes from performance measures that are further away from the merger event, this paper didn't consider performance changes beyond three years post-acquisition.

These measurement challenges notwithstanding, the finding of poor performance following foreign acquisitions, and possibly global expansions in general by UK firms is in line with real corporate stories of unsuccessful global expansions by UK firms including Marks \& Spencer, HMV, Next, among others. For instance, in the early 1990s, Next moved into the US market opening a couple of stores including one in Boston. It lost some millions of pounds on the venture before retreating. Similarly, following a series of losses, HMV closed its three remaining US stores in 2004, drawing a line under its loss-making American adventure.

\section{[INSERT TABLE 3]}

An important question arising from this finding of significant performance deterioration following foreign acquisitions is whether some types of firms are better able to squeeze more benefits from foreign acquisitions than others; or to put it differently, whether some types of firms are better able to utilise their prior foreign market experience to reduce the costs associated with internationalization. These issues are the focus of the next set of analyses.

\subsection{The moderating effect of acquirers' stage of internationalization}

There may be an asymmetric foreign acquisition impact on the performance of firms that enter foreign markets for the first time (domestic firms) and those firms that have prior presence in foreign markets (multinationals). The results of this test are reported in Models 5-12 of Table 3. In conducting these analyses, two separate dummies for domestic firms and multinationals are created and interacted with the average cross-border effect $\left(\beta_{4}\right)$ in the baseline model. Specifically, $\beta_{4}$ in Models $5-8$ is interacted with a dummy for domestic firms whilst $\beta_{4}$ in Models $9-12$ is interacted with a dummy variable for multinationals. Thus, these results show how the average negative cross-border 
performance effect differs between domestic firms (i.e. first time entrants into foreign markets) and multinationals (i.e. existing foreign market participants increasing their foreign operations).

The results indicate that the decline in corporate performance following foreign acquisitions is restricted to multinationals. In Models 5-8, foreign acquisitions do not seem to significantly reduce the performance (as measured by ROA, Tobin's Q, and operating costs) of domestic firms. Rather, these foreign deals seem to offer domestic corporations the opportunity to significantly boost their operating cash flows by about $2.3 \%$. Thus, domestic corporations seem to make some gains from foreign acquisitions. Meanwhile, Models 9-12 tell a completely different story about multinational. The performance measures across all four proxies exhibit a statistically significant decline following foreign acquisitions by existing multinationals. Whiles the ROA, Tobin's Q, and the operating cash flow of multinationals significantly declined, their operating cost significantly increased subsequent to the completion of foreign acquisitions. These findings generally appear to be inconsistent with the experiential learning literature which suggests that firms with prior experience in foreign markets should enjoy better performance.

At least two main reasons could explain these results. First, it is possible that domestic firms undertaking foreign acquisitions (i.e. first time entrants into foreign markets) may not be completely unknowledgeable about international business operations but could have gained some valuable foreign business experience through exporting. This is because firms often develop their international operations in small steps, rather than making large foreign acquisitions at single points in time. Johanson \& Valne (1977) show that firms typically start exporting to a country before they later establish a physical foreign presence in the host country. Therefore, the experiential learning advantage touted to be enjoyed by existing multinationals in a market over new entrants may be trivial. Second, it could be the case that the finding of negative foreign acquisition impact on the performance of multinationals is unduly driven by multinationals with very little experience in foreign markets. Some multinationals may have more foreign market experience than others, thus, a better test of the experiential learning hypothesis needs to distinguish between international firms with low or high levels of foreign exposure. 
This conjecture is tested by dividing the sample of multinational firms into terciles based on their foreign asset ratios and creating three separate dummies to represent each subsample. The present paper relies on the foreign asset ratios (FAR) to proxy for the extent of international business experience of multinationals. The first group of multinationals have low foreign asset ratios and are deemed to be at the early stages of their internationalization process, thus, they are expected to have very little experience in foreign market operations. The second group of multinationals have moderate foreign asset ratios while the final subsample has high foreign asset ratios. It is hoped that the second and final subsamples would represent those multinationals at mature stages of their internationalization strategies, and therefore have substantial experience in foreign market operations.

The three dummies are interacted with the key parameter of interest $\left(\beta_{4}\right)$ in an attempt to estimate the differential impact of foreign acquisitions on the performance of multinationals at different stages of the internationalization process. The results, reported in Table 4, show that the earlier finding of reduced performance of multinationals following foreign acquisitions was hugely influenced by the activities of multinationals at the early stage of their internationalization evolution (i.e. inexperienced multinationals). Specifically, when early-stage multinationals made foreign acquisitions, they experienced significantly poorer financial performance across all the performance proxies (see Models 1-4 of Table 4). Interestingly, it seems the ex-ante performance of early-stage multinationals is better than those of advanced-stage multinationals (see parameter estimates for the dummies for low, moderate, and high exposure firms in Table 4). Perhaps, earlier successes enjoyed in their first (or previous) international operations make these firms complacent and thus overestimate their ability (experience) to the extent that they undertake more risky foreign operations.

On the contrary, in Models 5-8, there is no statistically significant change in most of the performance proxies (Tobin's Q, operating cash flow, and operating costs) when foreign acquisitions are undertaken by multinational firms with moderate exposure to foreign markets. In fact, these firms seem to report significant performance improvements in terms of ROA. These results imply that the foreign market experiential learning advantage becomes more beneficial when a firm is at a matured stage of its internationalization process. These multinationals at the intermediate stage of 
internationalization perhaps learn from their earlier mistakes (when they were at the early stage) to improve upon their future international expansion decisions.

Finally, the results in Models 9-12 of Table 4 suggest that firms at a more advanced stage of their internationalization evolution tend to lose hold of their operational costs which then adversely affect their operating cash flows. They however manage (perhaps due to their substantial foreign market experience) to avoid significant declines in their bottom-line performance measures such as ROA and Tobin's Q. The rise (fall) in the operational cost (cash flow) of advanced-stage multinationals may be due to the increased coordination, communication, and governance costs associated with running a large, complex multinational organisation.

\section{[INSERT TABLE 4]}

\subsection{Control variables}

Until now, the discussion has only focused on $\beta_{4}$ in the model. This section turns attention to the discussion of the other explanatory variables in the regressions. To conserve space, this discussion is mainly concentrated on the models that are based on the entire sample (i.e. Models 1-4 of Table 3), but key variables in other models are also highlighted. First, it seems that, besides the foreign acquisition event (i.e. increasing levels of international diversification), those firms that engaged in foreign acquisitions generally had better ex-ante performance relative to their counterparts that engaged in domestic acquisitions. This is because, as depicted in Tables 3 and 4, the parameters for the foreign deal dummies $\left(\beta_{2}\right)$ are mostly positive and sometimes significant. This provides further support for the conclusion that managerial overconfidence may be driving the foreign acquisitions in the current article's sample and the resulting poor post-acquisition performance observed.

Second, $\beta_{3}$ (i.e. the parameter estimate for post-acquisition period) is mostly negative and significant. This suggests that acquisitions generally occur in periods of high competition (low profitability) in the macro-economy that leads firms to restructure/consolidate in order to stay competitive. Also, most of the other control variables have the predicted effect on firm performance (especially in the ROA, operating cash flow, and operating cost) and are also in line with most of the 
findings in prior studies. For example, firm size, employee productivity, capital intensity, and exchange rates have positive (negative) effect on ROA and operating cash flow (Tobin's Q and operating costs). However, financial leverage and $\mathrm{R} \& \mathrm{D}$ expenditure are negatively (positively) related to firm performance as measured by ROA and operating cash flow (Tobin's Q and operating costs). Further, firms that are diversified across several products and industries seem to be associated with lower performance.

Finally, to reflect the fact a firm may undertake several acquisitions in the sample period, the standard errors in all reported Models in Tables 3-5 are allowed to cluster by firm. When more conservative, time-clustered, standard errors are utilised to reflect the fact that M\&A transactions may also cluster over time (Harford, 2005), the key conclusions of the paper remain qualitatively unchanged.

\section{Robustness testing and further analysis}

This section conducts a number of analyses to test the robustness of our findings to alternative specifications. To conserve space, results are only reported for models with ROA as the dependent variable. First, our earlier analysis on the mediating role of prior foreign market exposure is based on a subsample analysis that relies on terciles of the foreign asset ratio. While this approach helps to examine the foreign acquisition-performance link within a specific subsample (e.g. those with low prior foreign market exposure), it is limited in revealing the relationships among the different subsamples. Therefore, an alternative approach based on an interaction terms of $\beta_{4}$ with quadratic and cubic transformations of the foreign asset ratio (i.e. FAR_2 and FAR_3) is utilised. As can be seen from Models 1-3 of Table 5, the interaction term $\left(\beta_{4}\right)$ is negative and significant only in Model 1 (the untransformed FAR). In Models 2-3, the interaction terms involving the transformed foreign asset ratios (representing higher levels of internationalization) are insignificant, suggesting that higher levels of internationalization are not associated with poor foreign acquisition performance.

Similarly, in Model 4, when all the interaction terms are included in a single regression, the negative foreign acquisition effect on performance is strongest $(-0.021)$ for the interaction term 
involving the untransformed FAR (low levels of internationalization), though not significant at conventional levels. These results are generally in line with the current article's general conclusion that the negative foreign acquisition performance may be driven by those multinational firms with low levels of internationalization.

Second, Ravenscraft and Scherer (1987) and Hong, Kaplan, and Mandelker (1978) suggest that the accounting method (pooling vs. purchase) used for the business combination may influence the acquisition performance. This is tested by taking advantage of the abolishing of the pooling of interest method in 2004 by IFRS 3, and restricting the accounting method for business combination to the purchase method. Therefore, the effect of the purchased accounting method is captured in $\beta_{4}$ by interacting the variable of interest with a dummy for post-2003 era (i.e. the period of compulsory application of the purchased method). The results, in Model 5, indicate that foreign acquisitions completed in the periods of exclusive application of the purchase accounting method did not significantly experience any superior or worse performance, compared with those completed when the pooling accounting method was allowed. This suggests that the distinction between pooling and purchased method of accounting for business combination is unlikely to significantly affect returns in foreign acquisitions.

Finally, the issue of whether a "merger of equals" impacts acquisition performance differently is considered. By using the amount paid for the target as a proxy for the size of target, a "merger of equals" is defined to include those deals in which the size of the target firm is at least $40 \%$ the size of the acquirer. Varying the $40 \%$ threshold did not significantly change the results. As shown in Model 6, the foreign acquisition effect on performance does not significantly differ between "mergers of equals" and other types of mergers.

[INSERT TABLE 5]

\section{Conclusion and managerial implications}

This paper utilises a mergers and acquisitions dataset to provide new empirical insights into the link between international corporate activity and firm performance. It relies on the international 
business and strategy literature to hypothesize and test how the decision by a firm to increase its international operations (via foreign acquisitions) may impact its financial performance. The findings indicate that relative to domestic acquisitions, foreign acquisitions (on average) result in declines in acquiring firms' financial performance (as measured by ROA, Tobin's Q, operating cash flow, and operating costs). However, the negative and significant foreign acquisition impact on corporate financial performance is primarily associated with existing multinational corporations at the early stages of their internationalization evolution (i.e. inexperienced multinationals). Interestingly, foreign acquisitions undertaken by domestic firms (new entrants into foreign markets) and by multinationals at mature stages of internationalization (i.e. more experienced MNCs) do not experience significant declines in their performance.

The results presented in this paper have several important implications on both corporate theory and practice. First, the decline in the financial performance of foreign acquirers suggests that international diversification is generally associated with more costs than benefits, at least in the shortterm. Therefore, managers, particularly the overconfident ones, who are contemplating international expansion through mergers and acquisitions should be more sceptical about the perceived benefits of these foreign deals and be prepared for some declines in their performance at least in the few years following the acquisition.

Second, the findings imply that the increased complexities (risks and costs) associated with international corporate activity is not symmetric for all acquiring firms. First time entrants into foreign markets (i.e. domestic firms undertaking foreign acquisitions) appear to be able to make smart choices in their foreign acquisition decisions, and are thus able to avoid poor financial performance subsequent to foreign acquisitions. A possible explanation is that the acquisition of a suitable local target firm by a domestic firm substantially ameliorates the absence of the foreign market experience on the part of the domestic firm. This is because the acquisition makes it possible for the domestic firm to utilise the organisational knowledge and experience of the local target firm. Also, the results suggest that the benefits of utilising prior foreign market experience and knowledge of the acquiring firm to manage the complexities in new foreign environments can only be realized by multinationals at mature stages of the internationalisation process. These results should encourage and embolden 
managers of domestic firms (and those with no prior foreign market experience) to consider using foreign acquisitions as a strategic tool to enter new markets, since the acquisition of a suitable target in the foreign country provides an effective mechanism for securing vital local knowledge and experience in the new market.

While we have attempted to control for several factors in the empirical analysis, data unavailability has made it impossible to control for firm's divestitures which may be an important determinant of M\&A success (Gugler et al., 2003). Also, the analysis of this article is based on a UK sample and thus generalisations of its conclusions should be done with caution. Future studies can extend this study by employing a global sample for its analysis in an attempt to examine the applicability of the findings outside the UK.

\section{Acknowledgements}

The author is grateful to an anonymous reviewer and the Editor-in-Chief, Ali M. Fatemi, of the Global Finance Journal for their valuable comments/suggestions. Any remaining errors are the author's sole responsibility.

\section{References}

Agyei-Boapeah, H., (2015). Cross-border acquisitions and financial leverage of UK acquirers. Accounting Forum, 39 (2), 97-108.

Agyei-Boapeah, H., (2017). Easing financing and M\&A investment constraints: The role of corporate industrial diversification. Annals of Economics and Finance, 18 (2), 277-290.

Agyei-Boapeah, H., Wang, Y., Tunyi, A., Machokoto, M., \& Zhang, F. (2018, In Press). Intangible investments and voluntary delisting: Mass exodus of Chinese firms from U.S. capital markets. International Journal of Accounting and Information Management.

Barkema, H.G., \& Vermeulen, F. (1998). International expansion through start-ups or acquisitions: A learning perspective. The Academy of Management Journal, 41, 7-26.

Berkovitch, E., \& Narayanan, M.P. (1993). Motives for takeovers: An empirical investigation. The Journal of Financial and Quantitative Analysis, 28(3), 347-362.

Bertrand, O., \& Capron, L. (2015). Productivity enhancement at home via cross-border acquisitions: The roles of learning and contemporaneous domestic investments. Strategic Management Journal, 36, 640-658.

Burgman, T. A. (1996). An empirical examination of multinational corporate capital structure. Journal of International Business Studies, 27(3), 553-570.

Davidson, W.H. (1980). The location of foreign investment activity: Country characteristics and experience effect. Journal of International Business Studies, 11(2), 9-22.

Denis, D.J., Denis, D. K., \& Yost, K. (2002). Global diversification, industrial diversification, and firm value. Journal of Finance, 57, 1951-1979.

Geringer, J.M., Tallman, S., \& Olsen, D.M. (2000). Product and geographic diversification among Japanese multinational firms. Strategic Management Journal, 21, 51-80.

Grant, R.M., Jammine, A.P., \& Thomas, H. (1988). Diversity, diversification, and profitability among British manufacturing companies. The Academy of Management Journal, 31(4), 771-801. 
Gugler, K. P., Mueller, D. C., Yurtoglu, B. B., \& Zulehner, C. (2003). The effects of mergers: An international comparison. International Journal of Industrial Organization, 21(5), 625-653.

Haleblain, J., \& Finkelstein, S. (1999). The influence of organisational acquisition experience on acquisition performance: A behavioural learning perspective. Administrative Science Quarterly, 44, 29-56.

Harford, J. (2005). What drives merger waves? Journal of Financial Economics, 77(3), 529-560.

Hitt, M.A., Hoskisson, R.E., \& Kim, H. (1997). International diversification: Effects on innovation and firm performance in product diversified firms. The Academy of Management Journal, 40, 767-798.

Hodgkinson, L., \& Partington, G.H. (2008). The motivation for takeovers in the UK. Journal of Business Finance \& Accounting, 35(1-2), 102-126.

Hong, H., Kaplan, R.S., \& Mandelker, G. (1978). Pooling vs. Purchase: The effects of accounting for mergers on stock prices. The Accounting Review, 53(1), 31-47.

Hout, T., Porter, M.E., \& Rudden, E. (1982). How global companies win out. Harvard Business Review, 60 (5), 98-108.

Hymer, S.H. (1976). A study of direct foreign investment. Cambridge, MA: MIT Press.

Johanson, J., \& Valne, J., (1977). The internationalization process of the firm: A model of knowledge development and increasing foreign market commitment. Journal of International Business Studies, 8(1), 23-32.

Johanson, J., \& Valne, J., (2009). The Uppsala internationalization process model revisited: From liability of foreignness to liability of outsidership. Journal of International Business Studies, 40(9), 1411-1431.

Jones, G.R., \& Hill, C.W.L. (1988). Transaction cost analysis of strategy structure choice. Strategic Management Journal, 9, 159-172.

Kogut, B., \& Chang, S.J. (1991). Technological capabilities of Japanese foreign direct investment in the United States. Review of Economics and Statistics, 73, 401-413.

Kostova, T., \& Roth, K. (2002). Adoption of an organisational practice by subsidiaries of multinational corporations: Institutional and relational effects. The Academy of Management Journal, 45, 215-233.

Krapl, A. A. (2015). Corporate international diversification and risk. International Review of Financial Analysis, $37,1-13$.

Lu, J.W., \& Beamish, P.W. (2001). The internationalization and performance of SMEs. Strategic Management Journal, 22, 565-586.

Lu, J.W., \& Beamish, P.W. (2004). International diversification and firm performance: The S-curve hypothesis. The Academy of Management Journal, 47(4), 598-609.

Mehran, H. (1995). Executive compensation structure, ownership, and firm performance. Journal of Financial Economics, 38, 163-184.

Paananen, M., \& Lin, H. (2009). The development of accounting quality of IAS and IFRS over time: The case of Germany. Journal of International Accounting Research, 8(1), 31-55.

Pangarkar, N. (2008). Internationalization and performance of small- and medium-sized enterprises. Journal of World Business, 43, 475-485.

Ravenscraft, D. J., \& Scherer, F.M. (1987). Life after takeover. The Journal of Industrial Economics, 36(2), 147-156.

Reeb, D.M., Mansi, S.A., \& Allee, J.M. (2001). Firm internationalization and the cost of debt financing: Evidence from non-provisional publicly traded debt. The Journal of Financial and Quantitative Analysis, 36(3), 395-414.

Shimizu, K., Hitt, M.A., Vaidyanath, D., \& Pisano, V. (2004). Theoretical foundations of cross-border mergers and acquisitions: A review of current research and recommendations for future research. Journal of International Management, 10, 307-353.

Sullivan, D. (1994). Measuring the degree of internationalization of a firm. Journal of International Business Studies, 25(2), 325-342.

United Nations Conference on Trade and Development (UNCTAD) (2014). World Investment Report. New York and Geneva: United Nations.

Very, P., \& Schweiger, D.M. (2001). The acquisition process as a learning process: Evidence from a study of critical problems and solutions in domestic and cross-border deals. Journal of World Business, 36(1), 1131.

Whittington, G. (2005). The adoption of International Accounting Standards in the European Union. European Accounting Review, 14(1), 127-153. 
Table 1: Acquisitions by UK firms during 1988-2014 organised by type of acquisitions and type of acquirers

\begin{tabular}{|c|c|c|c|c|c|c|c|}
\hline \multirow{2}{*}{ Years } & \multirow{2}{*}{ All } & \multicolumn{3}{|c|}{ Type of acquisition } & \multicolumn{3}{|c|}{ Type of firm } \\
\hline & & DA & FA & $\%$ of FA & DC & MNC & $\%$ of $\mathrm{MNC}$ \\
\hline 1988 & 16 & 16 & 0 & 0.00 & 16 & 0 & 0.00 \\
\hline 1989 & 54 & 48 & 6 & 0.11 & 47 & 7 & 0.13 \\
\hline 1990 & 64 & 50 & 14 & 0.22 & 58 & 6 & 0.09 \\
\hline 1991 & 117 & 105 & 12 & 0.10 & 100 & 17 & 0.15 \\
\hline 1992 & 254 & 183 & 71 & 0.28 & 133 & 121 & 0.48 \\
\hline 1993 & 316 & 197 & 119 & 0.38 & 139 & 177 & 0.56 \\
\hline 1994 & 442 & 291 & 151 & 0.34 & 187 & 255 & 0.58 \\
\hline 1995 & 500 & 323 & 177 & 0.35 & 170 & 330 & 0.66 \\
\hline 1996 & 482 & 296 & 186 & 0.39 & 163 & 319 & 0.66 \\
\hline 1997 & 578 & 369 & 209 & 0.36 & 250 & 328 & 0.57 \\
\hline 1998 & 621 & 425 & 196 & 0.32 & 282 & 339 & 0.55 \\
\hline 1999 & 618 & 365 & 253 & 0.41 & 259 & 359 & 0.58 \\
\hline 2000 & 634 & 388 & 246 & 0.39 & 280 & 354 & 0.56 \\
\hline 2001 & 478 & 265 & 213 & 0.45 & 172 & 306 & 0.64 \\
\hline 2002 & 348 & 210 & 138 & 0.40 & 120 & 228 & 0.66 \\
\hline 2003 & 313 & 173 & 140 & 0.45 & 107 & 206 & 0.66 \\
\hline 2004 & 358 & 223 & 135 & 0.38 & 137 & 221 & 0.62 \\
\hline 2005 & 451 & 251 & 200 & 0.44 & 169 & 282 & 0.63 \\
\hline 2006 & 468 & 270 & 198 & 0.42 & 180 & 288 & 0.62 \\
\hline 2007 & 595 & 322 & 273 & 0.46 & 179 & 416 & 0.70 \\
\hline 2008 & 433 & 211 & 222 & 0.51 & 90 & 343 & 0.79 \\
\hline 2009 & 224 & 121 & 103 & 0.46 & 64 & 160 & 0.71 \\
\hline 2010 & 249 & 138 & 111 & 0.45 & 94 & 155 & 0.62 \\
\hline 2011 & 281 & 137 & 144 & 0.51 & 73 & 208 & 0.74 \\
\hline 2012 & 240 & 133 & 107 & 0.45 & 63 & 177 & 0.74 \\
\hline 2013 & 277 & 173 & 104 & 0.38 & 89 & 188 & 0.68 \\
\hline
\end{tabular}




\begin{tabular}{|c|c|c|c|c|c|c|c|}
\hline 2014 & 8 & 7 & 1 & 0.13 & 7 & 1 & 0.13 \\
\hline Total & 9,419 & 5,690 & 3,729 & 0.40 & 3,628 & $\mathbf{5 , 7 9 1}$ & 0.61 \\
\hline
\end{tabular}

Table 2: Descriptive statistics and correlation matrix for variables

\begin{tabular}{|c|c|c|c|c|c|c|c|c|c|c|c|c|c|c|c|}
\hline No. & Variables & Mean & SD & Min. & Max. & 1 & 2 & 3 & 4 & 5 & 6 & 7 & 8 & 9 & 10 \\
\hline 1 & ROA & 0.04 & 0.15 & -0.96 & 0.26 & & & & & & & & & & \\
\hline 2 & Tobin's Q & 1.96 & 1.50 & 0.55 & 10.61 & 0.515 & & & & & & & & & \\
\hline 3 & Operating cash flow & 0.12 & 0.16 & -0.80 & 0.43 & 0.907 & 0.505 & & & & & & & & \\
\hline 4 & Operating cost & 0.30 & 0.27 & 0.01 & 1.81 & 0.080 & 0.213 & 0.174 & & & & & & & \\
\hline 5 & Firm age & 31.40 & 14.42 & 7.00 & 51.00 & 0.127 & -0.032 & 0.150 & -0.078 & & & & & & \\
\hline 6 & Employee productivity & 160.94 & 236.09 & 0.00 & 1638.00 & 0.002 & -0.154 & -0.065 & -0.056 & -0.026 & & & & & \\
\hline 7 & Firm size & 12.10 & 2.50 & 0.00 & 16.82 & 0.208 & 0.073 & 0.246 & -0.146 & 0.361 & 0.200 & & & & \\
\hline 8 & Financial leverage & 0.21 & 0.17 & 0.00 & 0.79 & -0.151 & -0.105 & -0.054 & -0.193 & 0.142 & 0.037 & 0.205 & & & \\
\hline 9 & Real asset base & 0.31 & 0.25 & 0.00 & 0.94 & 0.060 & -0.179 & 0.155 & -0.206 & 0.263 & -0.142 & 0.071 & 0.361 & & \\
\hline 10 & R\&D expenditure & 0.01 & 0.03 & 0.00 & 0.17 & 0.072 & 0.125 & 0.114 & 0.109 & 0.188 & 0.009 & 0.227 & -0.074 & -0.069 & \\
\hline 11 & Exchange rate & 1.66 & 0.17 & 1.44 & 2.00 & 0.028 & 0.013 & 0.004 & 0.023 & -0.098 & 0.039 & 0.006 & -0.019 & -0.105 & -0.009 \\
\hline
\end{tabular}

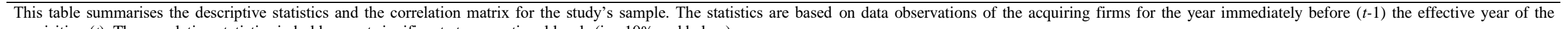
acquisition $(t)$. The correlation statistics in bold are not significant at conventional levels (i.e. 10\% and below). 
Table 3: The average impact of foreign acquisitions on the financial performance of acquiring firms

\begin{tabular}{|c|c|c|c|c|c|c|c|c|c|c|c|c|}
\hline \multirow{3}{*}{$\begin{array}{l}\text { Models } \\
\text { Explanatory variables }\end{array}$} & (1) & (2) & (3) & (4) & (5) & (6) & (7) & (8) & (9) & (10) & (11) & (12) \\
\hline & \multicolumn{4}{|c|}{ All firms } & \multicolumn{4}{|c|}{ Domestic firms } & \multicolumn{4}{|c|}{ Multinational firms } \\
\hline & ROA & $\mathbf{Q}$ & OCF & OC & ROA & $\mathbf{Q}$ & OCF & OC & ROA & $\mathbf{Q}$ & OCF & OC \\
\hline \multirow[t]{2}{*}{ Foreign acq. effect ( $\beta_{4}$ ) } & $-0.007 * *$ & $-0.056 * *$ & $-0.007 * *$ & $0.010 * * *$ & 0.016 & -0.062 & $0.023 * *$ & -0.005 & $-0.010 * * *$ & $-0.045^{*}$ & $-0.011 * * *$ & $0.011^{* * * *}$ \\
\hline & $(0.046)$ & $(0.044)$ & $(0.032)$ & $(0.014)$ & $(0.138)$ & $(0.477)$ & $(0.023)$ & $(0.719)$ & $(0.003)$ & $(0.088)$ & $(0.000)$ & $(0.006)$ \\
\hline \multirow[t]{2}{*}{ Foreign deal dummy ( $\beta_{2}$ ) } & 0.001 & $0.228 * * *$ & 0.005 & $-0.022 * * *$ & $-0.005^{*}$ & $0.158 * * *$ & -0.002 & $-0.017 * * *$ & 0.000 & $0.171 * * *$ & 0.005 & $-0.022 * * *$ \\
\hline & $(0.811)$ & $(0.000)$ & $(0.158)$ & $(0.000)$ & $(0.074)$ & $(0.000)$ & $(0.483)$ & $(0.002)$ & $(0.896)$ & $(0.000)$ & $(0.131)$ & $(0.000)$ \\
\hline \multirow[t]{2}{*}{ Post-acquisition dummy ( $\beta_{3}$ ) } & $-0.014 * * *$ & $-0.209 * * *$ & $-0.017 * * *$ & 0.000 & $-0.018 * * *$ & $-0.225 * * *$ & $-0.020 * * *$ & $0.004 *$ & $-0.013 * * *$ & $-0.211 * * *$ & $-0.015^{* * *}$ & 0.000 \\
\hline & $(0.000)$ & $(0.000)$ & $(0.000)$ & $(0.888)$ & $(0.000)$ & $(0.000)$ & $(0.000)$ & $(0.091)$ & $(0.000)$ & $(0.000)$ & $(0.000)$ & $(0.894)$ \\
\hline \multirow[t]{2}{*}{ Domestic firm dummy } & $\ldots$ & $\cdots$ & $\cdots$ & $\cdots$ & -0.005 & $-0.165 * * *$ & $-0.006^{*}$ & -0.003 & $\ldots$ & $\ldots$ & $\cdots$ & $\ldots$ \\
\hline & $\ldots$ & $\ldots$ & $\ldots$ & $\ldots$ & $(0.116)$ & $(0.000)$ & $(0.078)$ & $(0.968)$ & $\ldots$ & $\ldots$ & $\ldots$ & $\ldots$ \\
\hline \multirow[t]{2}{*}{ Multinational firm dummy } & $\ldots$ & $\ldots$ & $\ldots$ & $\ldots$ & $\ldots$ & $\ldots$ & $\ldots$ & $\ldots$ & 0.005 & $0.175 * * *$ & 0.005 & -0.001 \\
\hline & $\ldots$ & $\ldots$ & $\ldots$ & $\ldots$ & $\ldots$ & $\ldots$ & $\ldots$ & $\ldots$ & $(0.156)$ & $(0.000)$ & $(0.142)$ & $(0.938)$ \\
\hline \multirow[t]{2}{*}{ Firm age } & 0.000 & -0.001 & 0.000 & $-0.001 * * *$ & 0.000 & $-0.001 *$ & 0.000 & $-0.001 * * *$ & 0.001 & $-0.001 *$ & 0.000 & $-0.001 * * *$ \\
\hline & $(0.335)$ & $(0.115)$ & $(0.665)$ & $(0.000)$ & $(0.366)$ & $(0.063)$ & $(0.711)$ & $(0.000)$ & $(0.356)$ & $(0.065)$ & $(0.693)$ & $(0.000)$ \\
\hline \multirow[t]{2}{*}{ Employee productivity } & $0.001 * * *$ & $0.001 * * *$ & 0.000 & $-0.001 * * *$ & $0.002 * * *$ & $-0.004 * * *$ & 0.000 & $-0.001 * * *$ & $0.001 * * *$ & $-0.004 * * *$ & 0.000 & $-0.001 * * *$ \\
\hline & $(0.003)$ & $(0.000)$ & $(0.437)$ & $(0.000)$ & $(0.003)$ & $(0.000)$ & $(0.475)$ & $(0.000)$ & $(0.002)$ & $(0.000)$ & $(0.485)$ & $(0.000)$ \\
\hline \multirow[t]{2}{*}{ Firm size } & $0.023 * * *$ & $-0.029 * * *$ & $0.023 * * *$ & $-0.019 * * *$ & $0.023 * * *$ & $-0.039 * * *$ & $0.023 * * *$ & $-0.019 * * *$ & $0.023 * * *$ & $-0.039 * * *$ & $0.023 * * *$ & $-0.019 * * *$ \\
\hline & $(0.000)$ & $(0.003)$ & $(0.000)$ & $(0.000)$ & $(0.000)$ & $(0.000)$ & $(0.000)$ & $(0.000)$ & $(0.000)$ & $(0.000)$ & $(0.000)$ & $(0.000)$ \\
\hline \multirow[t]{2}{*}{ Financial leverage } & $-0.193 * * *$ & $0.477 * * *$ & $-0.136 * * *$ & $0.086^{* * *}$ & $-0.193 * * *$ & $0.479 * * *$ & $-0.136 * * *$ & $0.086^{* * *}$ & $-0.192 * * *$ & $0.480 * * *$ & $-0.136^{* * *}$ & $0.086 * * *$ \\
\hline & $(0.000)$ & $(0.000)$ & $(0.000)$ & $(0.000)$ & $(0.000)$ & $(0.000)$ & $(0.000)$ & $(0.000)$ & $(0.000)$ & $(0.000)$ & $(0.000)$ & $(0.000)$ \\
\hline \multirow[t]{2}{*}{ Capital intensity } & $0.105 * * *$ & $-0.252 * * *$ & $0.141 * * *$ & $-0.092 * * *$ & $0.105^{* * *}$ & $-0.231 * * *$ & $0.142 * * *$ & $-0.093 * * *$ & $0.105 * * *$ & $-0.232 * * *$ & $0.142 * * *$ & $-0.092 * * *$ \\
\hline & $(0.000)$ & $(0.000)$ & $(0.000)$ & $(0.000)$ & $(0.000)$ & $(0.001)$ & $(0.000)$ & $(0.000)$ & $(0.000)$ & $(0.001)$ & $(0.000)$ & $(0.000)$ \\
\hline \multirow[t]{2}{*}{$R \& D$ expenditure } & $-0.471 * * *$ & $0.339 * * *$ & $-0.337 * * *$ & $0.544 * * *$ & $-0.473 * * *$ & $0.218 * * *$ & $-0.339 * * *$ & $0.541 * * *$ & $-0.474 * * *$ & $0.216^{* * * *}$ & $-0.340 * * *$ & $0.543 * * *$ \\
\hline & $(0.000)$ & $(0.000)$ & $(0.004)$ & $(0.000)$ & $(0.000)$ & $(0.000)$ & (0.004) & $(0.000)$ & $(0.000)$ & $(0.000)$ & $(0.004)$ & $(0.000)$ \\
\hline \multirow[t]{2}{*}{ Missing R\&D dummy } & $0.008 * *$ & $0.260 * * *$ & $0.010 * * *$ & $0.061 * * *$ & $0.008 * * *$ & $0.274 * * *$ & $0.010^{* * *}$ & $0.061 * * *$ & $0.008 * * *$ & $0.273 * * *$ & $0.010 * * *$ & $0.061 * * *$ \\
\hline & $(0.015)$ & $(0.000)$ & $(0.006)$ & $(0.000)$ & $(0.013)$ & $(0.000)$ & $(0.005)$ & $(0.000)$ & $(0.013)$ & $(0.000)$ & $(0.005)$ & $(0.000)$ \\
\hline Product diversification & $-0.009 * * *$ & $-0.135^{* * *}$ & $-0.011 * * *$ & -0.006 & $-0.010 * * *$ & $-0.160 * * *$ & $-0.011 * * *$ & -0.006 & $-0.010 * * *$ & $-0.160 * * *$ & $-0.011 * * *$ & -0.006 \\
\hline
\end{tabular}




\begin{tabular}{|c|c|c|c|c|c|c|c|c|c|c|c|c|}
\hline & $(0.000)$ & $(0.000)$ & $(0.000)$ & $(0.264)$ & $(0.000)$ & $(0.000)$ & $(0.000)$ & $(0.264)$ & $(0.000)$ & $(0.000)$ & $(0.000)$ & $(0.258)$ \\
\hline \multirow[t]{2}{*}{ Exchange rate } & $0.035 * * *$ & $-0.685^{* * * *}$ & $0.013^{*}$ & $-0.046^{* * * *}$ & $0.036 * * *$ & $-0.686 * * *$ & $0.013^{*}$ & $-0.046 * * *$ & $0.036 * * *$ & $-0.685 * * *$ & $0.013^{*}$ & $-0.046^{* * * *}$ \\
\hline & $(0.000)$ & $(0.000)$ & $(0.082)$ & $(0.001)$ & $(0.000)$ & $(0.000)$ & $(0.076)$ & $(0.001)$ & $(0.000)$ & $(0.000)$ & $(0.079)$ & $(0.001)$ \\
\hline Industry dummies & Yes & Yes & Yes & Yes & Yes & Yes & Yes & Yes & Yes & Yes & Yes & Yes \\
\hline \multirow[t]{2}{*}{ Intercept $\left(\beta_{1}\right)$} & $-0.330 * * *$ & $0.140^{* * * *}$ & $-0.242 * * *$ & $0.574 * * *$ & $-0.324 * * *$ & $0.341 * * *$ & $-0.235 * * *$ & $0.574 * * *$ & $-0.330^{* * * *}$ & $0.169^{* * * *}$ & $-0.242^{* * *}$ & $0.575^{* * *}$ \\
\hline & $(0.000)$ & $(0.000)$ & $(0.000)$ & $(0.000)$ & $(0.000)$ & $(0.000)$ & $(0.000)$ & $(0.000)$ & $(0.000)$ & $(0.000)$ & $(0.000)$ & $(0.000)$ \\
\hline \multicolumn{13}{|l|}{$\underline{\text { Regression statistics }}$} \\
\hline Number of observations & 18,838 & 18,838 & 18,838 & 18,838 & 18,838 & 18,838 & 18,838 & 18,838 & 18,838 & 18,838 & 18,838 & 18,838 \\
\hline Number of acquiring firms & 9,419 & 9,419 & 9,419 & 9,419 & 9,419 & 9,419 & 9,419 & 9,419 & 9,419 & 9,419 & 9,419 & 9,419 \\
\hline Wald Chi-squared statistic & $1,201.72$ & $2,285.52$ & $1,860.30$ & $3,467.25$ & $1,219.56$ & $2,280.71$ & $1,863.46$ & $3,495.59$ & $1,236.06$ & $2,275.42$ & $1,889.24$ & $3,505.82$ \\
\hline R-squared: Within & 0.085 & 0.033 & 0.070 & 0.049 & 0.086 & 0.035 & 0.071 & 0.048 & 0.086 & 0.035 & 0.071 & 0.049 \\
\hline Between & 0.221 & 0.139 & 0.229 & 0.222 & 0.221 & 0.140 & 0.229 & 0.222 & 0.221 & 0.140 & 0.229 & 0.222 \\
\hline Overall & 0.177 & 0.114 & 0.184 & 0.192 & 0.177 & 0.115 & 0.184 & 0.192 & 0.177 & 0.115 & 0.184 & 0.192 \\
\hline
\end{tabular}

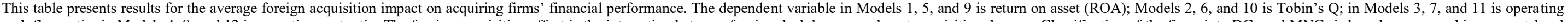

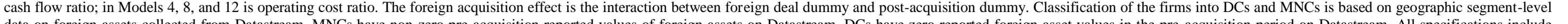

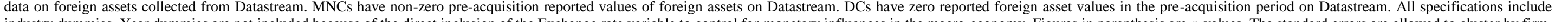

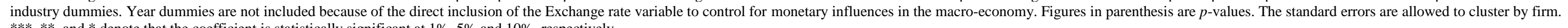
$* * *, * *$, and $*$ denote that the coefficient is statistically significant at $1 \%, 5 \%$ and $10 \%$, respectively. 
Table 4: Analysis of the levels of prior foreign market exposure

\begin{tabular}{|c|c|c|c|c|c|c|c|c|c|c|c|c|}
\hline \multirow{3}{*}{$\begin{array}{l}\text { Models } \\
\text { Explanatory variables }\end{array}$} & (1) & (2) & (3) & (4) & (5) & (6) & (7) & (8) & (9) & (10) & (11) & (12) \\
\hline & \multicolumn{4}{|c|}{ Low foreign market exposure firms } & \multicolumn{4}{|c|}{ Moderate foreign market exposure firms } & \multicolumn{4}{|c|}{ High foreign market exposure firms } \\
\hline & ROA & $\mathbf{Q}$ & OCF & OC & ROA & $\mathbf{Q}$ & OCF & OC & ROA & $\mathbf{Q}$ & OCF & OC \\
\hline Foreign acq. effect $\left(\beta_{4}\right)$ & $\begin{array}{c}-\mathbf{0 . 0 2 9} * * * \\
(0.000)\end{array}$ & $\begin{array}{c}-\mathbf{- 0 . 2 3 7} * * * \\
(0.000)\end{array}$ & $\begin{array}{c}-\mathbf{- 0 . 0 2 3} * * * \\
(0.000)\end{array}$ & $\begin{array}{c}\mathbf{0 . 0 3 0} * * * \\
(0.000)\end{array}$ & $\begin{array}{c}\mathbf{0 . 0 0 8}^{* *} \\
(0.019)\end{array}$ & $\begin{array}{l}\mathbf{- 0 . 0 1 9} \\
(0.564)\end{array}$ & $\begin{array}{c}\mathbf{0 . 0 0 4} \\
(0.198)\end{array}$ & $\begin{array}{l}-\mathbf{0 . 0 0 2} \\
(0.706)\end{array}$ & $\begin{array}{l}-\mathbf{0 . 0 0 4} \\
(0.292)\end{array}$ & $\begin{array}{c}\mathbf{0 . 0 4 6} \\
(0.141)\end{array}$ & $\begin{array}{c}-\mathbf{0 . 0 0 9} * * \\
(0.016)\end{array}$ & $\begin{array}{l}\mathbf{0 . 0 0 8 *} \\
(0.059)\end{array}$ \\
\hline Foreign deal dummy ( $\left.\beta_{2}\right)$ & $\begin{array}{c}0.001 \\
(0.682)\end{array}$ & $\begin{array}{c}0.229 * * * \\
(0.000)\end{array}$ & $\begin{array}{c}0.004 \\
(0.165)\end{array}$ & $\begin{array}{c}-0.020 * * * \\
(0.000)\end{array}$ & $\begin{array}{l}-0.003 \\
(0.229)\end{array}$ & $\begin{array}{c}0.189 * * * \\
(0.000)\end{array}$ & $\begin{array}{c}0.001 \\
(0.807)\end{array}$ & $\begin{array}{c}-0.019 * * * \\
(0.000)\end{array}$ & $\begin{array}{l}-0.001 \\
(0.612)\end{array}$ & $\begin{array}{c}0.192 * * * \\
(0.000)\end{array}$ & $\begin{array}{c}0.002 \\
(0.397)\end{array}$ & $\begin{array}{l}-0.010^{*} \\
(0.061)\end{array}$ \\
\hline Post-acquisition dummy ( $\beta_{3}$ ) & $\begin{array}{c}-0.015^{* * *} \\
(0.000)\end{array}$ & $\begin{array}{c}-0.212^{* * *} \\
(0.000)\end{array}$ & $\begin{array}{c}-0.018 * * * \\
(0.000)\end{array}$ & $\begin{array}{c}0.001 \\
(0.596)\end{array}$ & $\begin{array}{c}-0.018^{* * *} \\
(0.000)\end{array}$ & $\begin{array}{c}-0.228 * * * \\
(0.000)\end{array}$ & $\begin{array}{c}-0.020 * * * \\
(0.000)\end{array}$ & $\begin{array}{l}0.004 * \\
(0.097)\end{array}$ & $\begin{array}{c}-0.017 * * * \\
(0.000)\end{array}$ & $\begin{array}{c}-0.238 * * * \\
(0.000)\end{array}$ & $\begin{array}{c}-0.018 * * * \\
(0.000)\end{array}$ & $\begin{array}{c}0.002 \\
(0.511)\end{array}$ \\
\hline Low exposure dummy & $\begin{array}{c}0.013 * * * \\
(0.000)\end{array}$ & $\begin{array}{c}0.083 * * * \\
(0.011)\end{array}$ & $\begin{array}{c}0.011 * * * \\
(0.000)\end{array}$ & $\begin{array}{c}0.012 * * * \\
(0.033)\end{array}$ & $\begin{array}{l}\cdots \\
\cdots\end{array}$ & $\begin{array}{l}\cdots \\
\cdots\end{array}$ & $\begin{array}{l}\cdots \\
\cdots\end{array}$ & $\begin{array}{l}\cdots \\
\cdots\end{array}$ & $\begin{array}{l}\cdots \\
\cdots\end{array}$ & $\begin{array}{l}\cdots \\
\cdots\end{array}$ & $\begin{array}{l}\cdots \\
\cdots\end{array}$ & $\begin{array}{l}\cdots \\
\cdots\end{array}$ \\
\hline Moderate exposure dummy & $\begin{array}{l}\cdots \\
\cdots\end{array}$ & $\begin{array}{l}\cdots \\
\cdots\end{array}$ & $\begin{array}{l}\cdots \\
\cdots\end{array}$ & $\begin{array}{l}\cdots \\
\cdots\end{array}$ & $\begin{array}{l}-0.004 \\
(0.165)\end{array}$ & $\begin{array}{c}0.107 * * * \\
(0.001)\end{array}$ & $\begin{array}{c}-0.003 * * * \\
(0.375)\end{array}$ & $\begin{array}{c}0.018 * * * \\
(0.002)\end{array}$ & $\begin{array}{l}\cdots \\
\cdots\end{array}$ & $\begin{array}{l}\cdots \\
\cdots\end{array}$ & $\begin{array}{l}\cdots \\
\cdots\end{array}$ & $\begin{array}{l}\cdots \\
\cdots\end{array}$ \\
\hline High exposure dummy & $\begin{array}{l}\cdots \\
\cdots\end{array}$ & $\begin{array}{l}\cdots \\
\ldots\end{array}$ & $\begin{array}{l}\cdots \\
\cdots\end{array}$ & $\begin{array}{l}\cdots \\
\cdots\end{array}$ & $\begin{array}{l}\cdots \\
\cdots\end{array}$ & $\begin{array}{l}\cdots \\
\cdots\end{array}$ & $\begin{array}{l}\cdots \\
\ldots\end{array}$ & $\begin{array}{l}\cdots \\
\cdots\end{array}$ & $\begin{array}{l}-0.003 \\
(0.369)\end{array}$ & $\begin{array}{c}0.001 \\
(0.968)\end{array}$ & $\begin{array}{c}0.001 \\
(0.855)\end{array}$ & $\begin{array}{c}-0.045^{* * *} \\
(0.000)\end{array}$ \\
\hline Firm age & $\begin{array}{c}0.001 \\
(0.280)\end{array}$ & $\begin{array}{l}-0.001 \\
(0.124)\end{array}$ & $\begin{array}{c}0.000 \\
(0.600)\end{array}$ & $\begin{array}{c}-0.001 * * * \\
(0.000)\end{array}$ & $\begin{array}{c}0.001 \\
(0.326)\end{array}$ & $\begin{array}{l}-0.001 * \\
(0.074)\end{array}$ & $\begin{array}{c}0.000 \\
(0.658)\end{array}$ & $\begin{array}{c}-0.001 * * * \\
(0.000)\end{array}$ & $\begin{array}{c}0.001 \\
(0.301)\end{array}$ & $\begin{array}{l}-0.001 \\
(0.101)\end{array}$ & $\begin{array}{c}0.000 \\
(0.647)\end{array}$ & $\begin{array}{c}-0.001 * * * \\
(0.000)\end{array}$ \\
\hline Employee productivity & $\begin{array}{c}0.002 * * * \\
(0.002)\end{array}$ & $\begin{array}{c}-0.004 * * * \\
(0.000)\end{array}$ & $\begin{array}{c}0.000 \\
(0.465)\end{array}$ & $\begin{array}{c}-0.001 * * * \\
(0.000)\end{array}$ & $\begin{array}{c}0.001 * * * \\
(0.003)\end{array}$ & $\begin{array}{c}-0.004 * * * \\
(0.000)\end{array}$ & $\begin{array}{c}0.000 \\
(0.424)\end{array}$ & $\begin{array}{c}-0.001 * * * \\
(0.000)\end{array}$ & $\begin{array}{c}0.001 * * * \\
(0.003)\end{array}$ & $\begin{array}{c}-0.004 * * * \\
(0.000)\end{array}$ & $\begin{array}{c}0.000 \\
(0.449)\end{array}$ & $\begin{array}{c}-0.001 * * * \\
(0.000)\end{array}$ \\
\hline Firm size & $\begin{array}{c}0.023 * * * \\
(0.000)\end{array}$ & $\begin{array}{c}-0.030 * * * \\
(0.002)\end{array}$ & $\begin{array}{c}0.023 * * * \\
(0.000)\end{array}$ & $\begin{array}{c}-0.019 * * * \\
(0.000)\end{array}$ & $\begin{array}{c}0.023 * * * \\
(0.000)\end{array}$ & $\begin{array}{c}-0.030 * * * \\
(0.002)\end{array}$ & $\begin{array}{c}0.024 * * * \\
(0.000)\end{array}$ & $\begin{array}{c}-0.019 * * * \\
(0.000)\end{array}$ & $\begin{array}{c}0.023 * * * \\
(0.000)\end{array}$ & $\begin{array}{c}-0.028 * * * \\
(0.004)\end{array}$ & $\begin{array}{c}0.023 * * * \\
(0.000)\end{array}$ & $\begin{array}{c}-0.017 * * * \\
(0.000)\end{array}$ \\
\hline Financial leverage & $\begin{array}{c}-0.191 * * * \\
(0.000)\end{array}$ & $\begin{array}{c}0.485^{* * * *} \\
(0.000)\end{array}$ & $\begin{array}{c}-0.135^{* * *} \\
(0.000)\end{array}$ & $\begin{array}{c}0.088^{* * * *} \\
(0.000)\end{array}$ & $\begin{array}{c}-0.193 * * * \\
(0.000)\end{array}$ & $\begin{array}{c}0.480 * * * \\
(0.000)\end{array}$ & $\begin{array}{c}-0.137 * * * \\
(0.000)\end{array}$ & $\begin{array}{c}0.087 * * * \\
(0.000)\end{array}$ & $\begin{array}{c}-0.192 * * * \\
(0.000)\end{array}$ & $\begin{array}{c}0.472 * * * \\
(0.000)\end{array}$ & $\begin{array}{c}-0.136^{* * *} \\
(0.000)\end{array}$ & $\begin{array}{c}0.094 * * * \\
(0.000)\end{array}$ \\
\hline Capital intensity & $\begin{array}{c}0.105 * * * \\
(0.000)\end{array}$ & $\begin{array}{c}-0.251 * * * \\
(0.000)\end{array}$ & $\begin{array}{c}0.141 * * * \\
(0.000)\end{array}$ & $\begin{array}{c}-0.094 * * * \\
(0.000)\end{array}$ & $\begin{array}{c}0.105^{* * *} \\
(0.000)\end{array}$ & $\begin{array}{c}-0.245^{* * *} \\
(0.001)\end{array}$ & $\begin{array}{c}0.141^{* * *} \\
(0.000)\end{array}$ & $\begin{array}{c}-0.092 * * * \\
(0.000)\end{array}$ & $\begin{array}{c}0.104 * * * \\
(0.000)\end{array}$ & $\begin{array}{c}-0.249 * * * \\
(0.000)\end{array}$ & $\begin{array}{c}0.141 * * * \\
(0.000)\end{array}$ & $\begin{array}{c}-0.097 * * * \\
(0.000)\end{array}$ \\
\hline$R \& D$ expenditure & $\begin{array}{c}-0.476 * * * \\
(0.000)\end{array}$ & $\begin{array}{c}0.320 * * * \\
(0.000)\end{array}$ & $\begin{array}{c}-0.341 * * * \\
(0.003)\end{array}$ & $\begin{array}{c}0.529 * * * \\
(0.000)\end{array}$ & $\begin{array}{c}-0.470 * * * \\
(0.000)\end{array}$ & $\begin{array}{c}0.298 * * * \\
(0.000)\end{array}$ & $\begin{array}{c}-0.336^{* * *} \\
(0.004)\end{array}$ & $\begin{array}{c}0.534 * * * \\
(0.000)\end{array}$ & $\begin{array}{c}-0.473^{* * *} \\
(0.000)\end{array}$ & $\begin{array}{c}0.367 * * * \\
(0.000)\end{array}$ & $\begin{array}{c}-0.340^{* * *} \\
(0.004)\end{array}$ & $\begin{array}{c}0.523 * * * \\
(0.000)\end{array}$ \\
\hline Missing R\&D dummy & $0.008 * *$ & $0.259 * * *$ & $0.010 * * *$ & $0.061 * * *$ & $0.008 * *$ & $0.264 * * *$ & $0.010 * * *$ & $0.061 * * *$ & $0.008 * *$ & $0.263 * * *$ & $0.010 * * *$ & $0.058 * * *$ \\
\hline
\end{tabular}




\begin{tabular}{|c|c|c|c|c|c|c|c|c|c|c|c|c|}
\hline & $(0.018)$ & $(0.000)$ & $(0.007)$ & $(0.000)$ & $(0.017)$ & $(0.000)$ & $(0.006)$ & $(0.000)$ & $(0.020)$ & $(0.000)$ & $(0.008)$ & $(0.000)$ \\
\hline Product diversification & $\begin{array}{c}-0.010 * * * \\
(0.000)\end{array}$ & $\begin{array}{c}-0.142 * * * \\
(0.000)\end{array}$ & $\begin{array}{c}-0.012 * * * \\
(0.000)\end{array}$ & $\begin{array}{l}-0.007 \\
(0.194)\end{array}$ & $\begin{array}{c}-0.009 * * * \\
(0.000)\end{array}$ & $\begin{array}{c}-0.139 * * * \\
(0.000)\end{array}$ & $\begin{array}{c}-0.011 * * * \\
(0.000)\end{array}$ & $\begin{array}{l}-0.006 \\
(0.223)\end{array}$ & $\begin{array}{c}-0.009 * * * \\
(0.000)\end{array}$ & $\begin{array}{c}-0.136^{* * * *} \\
(0.000)\end{array}$ & $\begin{array}{c}-0.011 * * * \\
(0.000)\end{array}$ & $\begin{array}{l}-0.004 \\
(0.422)\end{array}$ \\
\hline Exchange rate & $\begin{array}{c}0.036 * * * \\
(0.000)\end{array}$ & $\begin{array}{c}-0.685^{* * *} \\
(0.000)\end{array}$ & $\begin{array}{c}0.013 * * * \\
(0.079)\end{array}$ & $\begin{array}{c}-0.045^{* * *} \\
(0.001)\end{array}$ & $\begin{array}{c}0.035^{* * *} \\
(0.000)\end{array}$ & $\begin{array}{c}-0.692 * * * \\
(0.000)\end{array}$ & $\begin{array}{l}0.013 * \\
(0.080)\end{array}$ & $\begin{array}{c}-0.047 * * * \\
(0.001)\end{array}$ & $\begin{array}{c}0.035^{* * * *} \\
(0.000)\end{array}$ & $\begin{array}{c}-0.685^{* * * *} \\
(0.000)\end{array}$ & $\begin{array}{l}0.013 * \\
(0.080)\end{array}$ & $\begin{array}{c}-0.047 * * * \\
(0.001)\end{array}$ \\
\hline Industry dummies & Yes & Yes & Yes & Yes & Yes & Yes & Yes & Yes & Yes & Yes & Yes & Yes \\
\hline Intercept $\left(\beta_{1}\right)$ & $\begin{array}{c}-0.331 * * * \\
(0.000)\end{array}$ & $\begin{array}{c}0.142^{* * * *} \\
(0.000)\end{array}$ & $\begin{array}{c}-0.242 * * * \\
(0.000)\end{array}$ & $\begin{array}{c}0.568^{* * * *} \\
(0.000)\end{array}$ & $\begin{array}{c}-0.329 * * * \\
(0.000)\end{array}$ & $\begin{array}{c}0.177 * * * \\
(0.000)\end{array}$ & $\begin{array}{c}-0.241^{* * *} \\
(0.000)\end{array}$ & $\begin{array}{c}0.579 * * * \\
(0.000)\end{array}$ & $\begin{array}{c}-0.330 * * * \\
(0.000)\end{array}$ & $\begin{array}{c}0.149 * * * \\
(0.000)\end{array}$ & $\begin{array}{c}-0.242^{* * *} \\
(0.000)\end{array}$ & $\begin{array}{c}0.570 * * * \\
(0.000)\end{array}$ \\
\hline \multicolumn{13}{|l|}{$\underline{\text { Regression statistics }}$} \\
\hline Number of observations & 18,838 & 18,838 & 18,838 & 18,838 & 18,838 & 18,838 & 18,838 & 18,838 & 18,838 & 18,838 & 18,838 & 18,838 \\
\hline Number of acquiring firms & 9,419 & 9,419 & 9,419 & 9,419 & 9,419 & 9,419 & 9,419 & 9,419 & 9,419 & 9,419 & 9,419 & 9,419 \\
\hline Wald Chi-squared statistic & $1,221.81$ & $2,288.85$ & $1,860.18$ & $3,487.59$ & $1,202.99$ & $2,288.30$ & $1,858.90$ & $3,488.10$ & $1,193.95$ & $2,287.92$ & $1,852.22$ & $3,523.59$ \\
\hline R-squared: Within & 0.087 & 0.036 & 0.072 & 0.050 & 0.085 & 0.033 & 0.070 & 0.048 & 0.085 & 0.033 & 0.071 & 0.050 \\
\hline Between & 0.222 & 0.140 & 0.230 & 0.223 & 0.221 & 0.140 & 0.229 & 0.223 & 0.221 & 0.139 & 0.229 & 0.225 \\
\hline Overall & 0.178 & 0.114 & 0.185 & 0.193 & 0.177 & 0.114 & 0.184 & 0.193 & 0.177 & 0.113 & 0.184 & 0.195 \\
\hline
\end{tabular}


Table 5: Robustness testing - Dependent variable in all models is return on asset (ROA)

\begin{tabular}{|c|c|c|c|c|c|c|}
\hline Models & (1) & (2) & (3) & (4) & (5) & (6) \\
\hline Models including: & FAR & FAR-2 & FAR-3 & FAR-all & Purchase & Equals \\
\hline \multirow[t]{2}{*}{ B 4 FAR } & $-0.013^{* *}$ & & & -0.021 & & \\
\hline & $(0.033)$ & & & $(0.118)$ & & \\
\hline \multirow[t]{2}{*}{ FAR } & -0.010 & & & $0.026^{*}$ & & \\
\hline & $(0.166)$ & & & $(0.098)$ & & \\
\hline \multirow[t]{2}{*}{ B4*FAR_squared } & & 0.000 & & 0.013 & & \\
\hline & & $(0.890)$ & & $(0.437)$ & & \\
\hline \multirow[t]{2}{*}{ FAR_squared } & & $-0.007 * * *$ & & $-0.035 * *$ & & \\
\hline & & $(0.000)$ & & $(0.035)$ & & \\
\hline \multirow[t]{2}{*}{ B4*FAR_cubed } & & & 0.000 & -0.001 & & \\
\hline & & & $(0.474)$ & $(0.493)$ & & \\
\hline \multirow[t]{2}{*}{ FAR_cubed } & & & $-0.001 * * *$ & $0.003 *$ & & \\
\hline & & & $(0.000)$ & $(0.086)$ & & \\
\hline \multirow[t]{2}{*}{ B4*Post_2003_era } & & & & & 0.004 & \\
\hline & & & & & $(0.342)$ & \\
\hline \multirow[t]{2}{*}{ Post-2003_era dummy } & & & & & $-0.022 * * *$ & \\
\hline & & & & & $(0.000)$ & \\
\hline \multirow[t]{2}{*}{ B4*Equals_merge } & & & & & & -0.014 \\
\hline & & & & & & $(0.197)$ \\
\hline \multirow[t]{2}{*}{ Equals_merge dummy } & & & & & & $-0.020 * * *$ \\
\hline & & & & & & $(0.000)$ \\
\hline \multirow[t]{2}{*}{ Foreign deal dummy } & 0.004 & -0.001 & -0.002 & 0.001 & -0.003 & -0.001 \\
\hline & $(0.256)$ & $(0.806)$ & $(0.505)$ & $(0.828)$ & $(0.370)$ & $(0.581)$ \\
\hline \multirow[t]{2}{*}{ Post-acq. dummy } & $-0.014 * * *$ & $-0.017 * * *$ & $-0.017 * * *$ & $-0.013 * * *$ & $-0.018 * * *$ & $-0.017 * * *$ \\
\hline & $(0.000)$ & $(0.000)$ & $(0.000)$ & $(0.000)$ & $(0.000)$ & $(0.000)$ \\
\hline \multirow[t]{2}{*}{ Firm age } & 0.000 & 0.000 & 0.000 & 0.000 & -0.000 & 0.000 \\
\hline & $(0.114)$ & $(0.159)$ & $(0.194)$ & $(0.184)$ & $(0.352)$ & $(0.394)$ \\
\hline
\end{tabular}




\begin{tabular}{|c|c|c|c|c|c|c|}
\hline Employee productivity & $\begin{array}{c}0.000 * * * \\
(0.001)\end{array}$ & $\begin{array}{c}0.000 * * * \\
(0.001)\end{array}$ & $\begin{array}{c}0.000 * * * \\
(0.001)\end{array}$ & $\begin{array}{c}0.000 * * * \\
(0.000)\end{array}$ & $\begin{array}{c}0.000 * * * \\
(0.000)\end{array}$ & $\begin{array}{c}0.000 * * * \\
(0.001)\end{array}$ \\
\hline Firm size & $\begin{array}{c}0.024 * * * \\
(0.000)\end{array}$ & $\begin{array}{c}0.023 * * * \\
(0.000)\end{array}$ & $\begin{array}{c}0.023^{* * *} * \\
(0.000)\end{array}$ & $\begin{array}{c}0.023 * * * \\
(0.000)\end{array}$ & $\begin{array}{c}0.024 * * * \\
(0.000)\end{array}$ & $\begin{array}{c}0.023 * * * \\
(0.000)\end{array}$ \\
\hline Financial leverage & $\begin{array}{c}-0.192^{* * *} \\
(0.000)\end{array}$ & $\begin{array}{c}-0.192 * * * \\
(0.000)\end{array}$ & $\begin{array}{c}-0.194 * * * \\
(0.000)\end{array}$ & $\begin{array}{c}-0.190 * * * \\
(0.000)\end{array}$ & $\begin{array}{c}-0.192 * * * \\
(0.000)\end{array}$ & $\begin{array}{c}-0.190 * * * \\
(0.000)\end{array}$ \\
\hline Capital intensity & $\begin{array}{c}0.104 * * * \\
(0.000)\end{array}$ & $\begin{array}{c}0.105 * * * \\
(0.000)\end{array}$ & $\begin{array}{c}0.106^{* * * *} \\
(0.000)\end{array}$ & $\begin{array}{c}0.104 * * * \\
(0.000)\end{array}$ & $\begin{array}{c}0.096 * * * \\
(0.000)\end{array}$ & $\begin{array}{c}0.104 * * * \\
(0.000)\end{array}$ \\
\hline R\&D expenditure & $\begin{array}{c}-0.398^{* * *} \\
(0.001)\end{array}$ & $\begin{array}{c}-0.395^{* * *} \\
(0.001)\end{array}$ & $\begin{array}{c}-0.395 * * * \\
(0.001)\end{array}$ & $\begin{array}{c}-0.390 * * * \\
(0.001)\end{array}$ & $\begin{array}{c}-0.457 * * * \\
(0.000)\end{array}$ & $\begin{array}{c}-0.468^{* * * *} \\
(0.000)\end{array}$ \\
\hline Missing R\&D dummy & $\begin{array}{c}0.010 * * * \\
(0.003)\end{array}$ & $\begin{array}{c}0.011 * * * \\
(0.001)\end{array}$ & $\begin{array}{c}0.011 * * * \\
(0.001)\end{array}$ & $\begin{array}{c}0.012 * * * \\
(0.001)\end{array}$ & $\begin{array}{c}0.009 * * * \\
(0.008)\end{array}$ & $\begin{array}{c}0.007 * * \\
(0.029)\end{array}$ \\
\hline Product diversification & $\begin{array}{c}-0.009 * * * \\
(0.000)\end{array}$ & $\begin{array}{c}-0.009 * * * \\
(0.000)\end{array}$ & $\begin{array}{c}-0.009 * * * \\
(0.000)\end{array}$ & $\begin{array}{c}-0.009 * * * \\
(0.000)\end{array}$ & $\begin{array}{c}-0.008^{* * *} \\
(0.003)\end{array}$ & $\begin{array}{c}-0.009 * * * \\
(0.001)\end{array}$ \\
\hline Exchange rate & $\begin{array}{c}0.037 * * * \\
(0.000)\end{array}$ & $\begin{array}{c}0.036^{* * *} \\
(0.000)\end{array}$ & $\begin{array}{c}0.036^{* * * *} \\
(0.000)\end{array}$ & $\begin{array}{c}0.035 * * * \\
(0.000)\end{array}$ & $\begin{array}{c}0.069 * * * \\
(0.000)\end{array}$ & $\begin{array}{c}0.038 * * * \\
(0.000)\end{array}$ \\
\hline Industry fixed effect & Yes & Yes & Yes & Yes & Yes & Yes \\
\hline Constant & $\begin{array}{c}-0.334^{* * *} \\
(0.000)\end{array}$ & $\begin{array}{c}-0.330 * * * \\
(0.000)\end{array}$ & $\begin{array}{c}-0.329 * * * \\
(0.000)\end{array}$ & $\begin{array}{c}-0.328 * * * \\
(0.000)\end{array}$ & $\begin{array}{c}-0.373 * * * \\
(0.000)\end{array}$ & $\begin{array}{c}-0.330 * * * \\
(0.000)\end{array}$ \\
\hline No. of observations & 17,920 & 17,920 & 17,920 & 17,920 & 18,838 & 18,838 \\
\hline No. of firms & 9,419 & 9,419 & 9,419 & 9,419 & 9,419 & 9,419 \\
\hline
\end{tabular}

